\title{
27 Training Need Analysis for Contract Employees (Study Case at PT. SCI Laboratory Surabaya)
}

\author{
Agustin Welliana Rahmawati Putri ${ }^{1 *}$, Bustanul Arifin Noer ${ }^{2}$
}

\begin{abstract}
PT. Sucofindo (SCI) is a company engaged in the fields of inspection, supervision, testing and assessment. There are a lot of services offered by PT. SCI, the role of human resources needs to be put in concern given the increasingly widespread challenges of competence. The company's efforts in that employees have the ability and good performance, namely by conducting training for employee self-development. To be able to understand the importance of training for contract employees of PT. SCI Laboratory Surabaya, this study used the theory of Training Need Analysis (TNA), an analysis of training needs for contract employees. The research sample was taken in a survey of 97 employees of PT. SCI Surabaya laboratory. With the method of Focus Group Discussion (FGD) and Training need assessment-tools (TNA-T) to analyze the training needs for contract employees at PT. SCI Laboratory Surabaya. The results of the study using the TNA-T method were PT. SCI Surabaya Laboratory's contract employees still need training. The design of TNA for 2019 is the training of Chemical AK3 as many as 34 people for Office Operations using the off job training method, 27 people need method validation training, and 15 people need training in analysis according to the santart method. TNA for 33 field operations employees needed method validation training and 17 people needed draft survey operation training. Training other than AK3 Chemistry is recommended to use the on job training method.
\end{abstract}

Keywords-Training Need Analysis-Tools (TNA-T), Focus Group Discussion (FGD), On Job Training, Off Job Training.

\section{INTRODUCTION ${ }^{1}$}

The success of contract and outsourcing employees is a challenge that must be eliminated because not all companies are truly ready to have permanent employees with all that is related. There is a fact that certain types of businesses contain high uncertainties so that it is a big risk if the company directly appoints permanent employees. However, the risks that may occured from contract employees include productivity which decreases if the selected contract employee company is incompetent and misplaces employees in certain positions, if the selection, training and placement process is not carried out carefully by the company.

\footnotetext{
${ }^{1}$ Agustin Welliana Rahmawati Putri and Bustanul Arifin Noer are with Departement of Business and Management Technology, Institut Teknologi Sepuluh Nopember, Surabaya, 60111, Indonesia. E-mail: agustinwrputri@gmail.com; bus4arifin@gmail.com.
}

PT. Sucofindo (SCI) is a company engaged in inspection, supervision, testing and assessment. Starting from the development of trade activities, especially on agricultural commodities, the smooth flow of goods and safeguards of foreign exchange in the export-import trade, then through the creativity of PT. SCI forms new service innovations on the basis of its competencies along with the development of the needs of the business world. The first service business unit owned by PT. SCI is cargo superintendence \& inspection, then through analysis study and innovation at PT. SCI has diversified its services, thus giving birth to warehousing \& forwarding services, analytical laboratories, industrial \& marine engineering, engineering \& industrial hygiene.

Therefore, sufficient and competent human resources are demanded and have competitive competitiveness in carrying out their roles and functions both for individuals and company goals. One of the company's efforts so that employees have good abilities and performance, namely by conducting training for employee self-development in the form of training. Training is a systematic process to change the work behavior of a person / group of employees in an effort to improve performance. From this phenomenon, the authors are interested in examining how the influence of training is only done once, on performance. Similarly, the influence of motivation on performance (Ivancevich, 2008).

All training and development programs carried out by the company aim to cover the gap or the gap between employees and job requests, in addition to increasing the efficiency and effectiveness of employees in achieving work goals [1].

Other phenomena that occur in the field based on interview information from the Operational support section staff of PT. Surabaya SCI Laboratory, only provides onceon-time training when placing employees, while most employees are employees who have worked for more than 5 years [2].

From the data on Table 1 and Table 2, it can be seen that there are still many contract employees who have not received training, this can lead to poor performance in their fields. 
TABLE 1.

LisT OF NUMBER EMPLOYEE AT PT. SCI LABORATORY SURABAYA 2017

\begin{tabular}{cccc}
\hline \hline Sub-Division & $\begin{array}{c}\text { Permanent } \\
\text { Employees }\end{array}$ & $\begin{array}{c}\text { Contracts } \\
\text { Employees }\end{array}$ & $\begin{array}{c}\text { Number Of } \\
\text { Employee }\end{array}$ \\
\hline Administration & 6 & 15 & 21 \\
Enviro, Micro, General & 5 & 42 & 47 \\
Coal And Mining & 14 & 30 & 44 \\
Total & $\mathbf{3 9}$ & $\mathbf{1 1 2}$ & $\mathbf{1 5 1}$ \\
\hline \hline
\end{tabular}

TABLE 2

LIST OF TYPES OF CONTRACT EMPLOYEES TRAINING AT PT. SCI LABORATORY SURABAYA 2017

\begin{tabular}{llc}
\hline \hline \multicolumn{1}{c}{$\begin{array}{c}\text { Sub- } \\
\text { Division }\end{array}$} & \multicolumn{1}{c}{ Type of Training } & $\begin{array}{c}\text { Employee Contracts } \\
\text { that follow training }\end{array}$ \\
\hline Micro & $\begin{array}{l}\text { Quality Control } \\
\text { Food Microbiology Analysis } \\
\text { Training }\end{array}$ & 2 \\
& $\begin{array}{l}\text { Quality Control } \\
\text { AK3 Chemistry Training }\end{array}$ & 4 \\
Enviroment & 3 \\
& Clean Water Analysis & 3 \\
& Training & 2 \\
Enviro, & Refined Sugar Training & 4 \\
Micro, & General K3 Training & 5 \\
Coal and & Inhouse Training for B3 & 5 \\
Mining, & waste treatment & 3 \\
Serco & ISO 17025: 2015 Training & 4 \\
\hline Coal and & Draugh Survey & 3 \\
Mining & Inhouse Training Coal & 3 \\
& ISO 17020: 2012 Training & 2 \\
\hline General & Validation of Methods and & \\
\hline \hline
\end{tabular}

Effective training can make employees become professionals and strongly maintain the fields they hold. In the interview the head of the Human Resources (HR) PT. The SCI Laboratory Surabaya provided information that so far the determination of training needs had not been implemented. Where training participants are selected on the basis of the policies of each head of field and the length of time the employee works. This will affect the gap, performance and motivation of employees who are not chosen to do work.

To be able to comprehend the importance of training PT Surabaya SCI Laboratory employees, this study used the theory of Training Need Analysis (TNA), an analysis of training needs for contract employees. TNA is very effective and important in workplaces that are changing rapidly in this era, starting from new technologies and increasing and less flexible employee performance, leading to appropriate changes in the skills and abilities needed by employees.

TNA is a training need at the level of employees, departments or organizations to assist organizations in working effectively and employee performance in improving company competencies. The aim of TNA is to ensure that training addresses existing problems, tailored to organizational goals, is delivered in an effective and costeffective manner, and employees can be responsible for their fields.

\section{LITERATURE REVIEW}

\section{A. Definition of Human Resources}

HRM is a policy and practice that is needed by someone to carry out the "person" aspect or HR from a management position, including recruitment, screening, training, compensation and assessment. HR management activities in an organization have the same basic functions in management functions. The management function applied in the HR field is [3].

Human resource management is a management function that can assist leaders in resolving labor issues, such as providing, evaluating performance, developing motivation and dismissing employees to achieve the interests of companies and employees.

\section{B. Job Training}

Training is a short-term educational process that uses systematic and organized procedures in which nonmanagerial employees learn knowledge and technical skills in limited goals. From some of the training meanings explained above, it can be concluded that training is a process to get good job skills through a series of systematic procedures carried out by an expert who aims to improve skills and knowledge to employees.

Some methods used by a company in implementing training programs, namely:

\section{1) On the job training (in work)}

This training takes the form of assigning employees under the guidance of experienced supervisors (seniors). Included in the job training method are as follows:
a. Job instruction training
b. Job rotation
c. Apprenticeship
d. Coaching

2) Off the job training (Out of work)

Training using this method means that employees as trainees temporarily leave their activities, tasks and work. Included in this method are:
a. Lecture
b. Vestibula Training
c. Behavior Modeling
d. Simulation

\section{Training Need Analysis (TNA)}

Training Needs Analysis (TNA) is a systematic study of an educational problem by collecting data and information from various sources, to obtain problem solving or suggestions for further action. TNA is an analysis of workplace needs specifically intended to determine what training needs are indeed a priority. Information on these needs will help companies effectively use resources (time, funds, etc.) while avoiding unnecessary training activities. TNA can also be understood as a systematic and comprehensive investigation of various problems in order to identify precisely the dimensions of the problem in such a way that the company can finally find out whether the 
problem really needs to be solved through a training program or not.

TNA can help identify the right people and the right program while consideration (training department) and consideration programs can help in creating the actual conditions.

Training Need Analysis (TNA) is a systematic investigation of training needs in order to achieve expected performance. In identifying TNA three approaches were carried out, namely organizational analysis, job analysis and individual analysis. Organizational analysis identifies overall organizational needs based on the development of the organization's environment. Job analysis identifies skills requirements based on job descriptions (expected skills standards and technical standards). While individual analysis identifies training needs according to individual needs.

The Training Need Assessment Tool (TNA-T) method is used to analyze the gap in current capabilities with the skills needed by employees, namely the work ability of an employee to do the work assigned to them. If the gap between the capabilities possessed today and the required abilities is due to the low level of knowledge, skills and attitudes, the solution is training. The difference between the ability possessed at this time and the ability needed is a lack of abilities that need to be trained. In other words, the abilities that are currently possessed and the required abilities are added with training. So it was concluded that training was carried out to overcome the inadequacy of trained work.

The technique of determining training using the TNA-T method has advantages and disadvantages. The advantages possessed compared to other techniques are in terms of minimizing subjective judgments from the party giving the assessment and the party being assessed, while the weakness is if the person who gives the assessment or is considered not giving honest information is actually biased [3].

\section{Focus Group Discussion}

The method to be discussed is Focus Group Discussion (FGD). According to Krueger (1994: 5-10), this method is a data collection technique to get the perceptions and views of each individual about a theme in a particular area of study. FGDs are built on assumptions:

a. Individual limitations are always hidden in ignorance of these personal weaknesses;

b. Each group member gives knowledge to each other in group association;

c. Each individual is controlled by another individual, so he strives to be the best;

d. Subjective weaknesses lie in individual weaknesses that are difficult to control by the individual concerned.

Intersubjectives always approach the best truth at that time. In addition, group thinking is more perfect than individual thinking. This is because the excess of individual thinking is always limited by frame of reference.

\section{Methodology}

\section{A. Type of Research}

This study picked a qualitative method because this research is a descriptive research in which to ascertain and describe variables that lead to the process of analyzing training needs effectively. Data were collected through questionnaires, surveys of 97 contract employees and HR head interviews at PT. SCI Surabaya Branch Laboratory.

TABLE 3.

TRAINING NEED ASSESSMENT FOR CONTRACT EMPLOYEE OFFICE OPERATION AT PT. SCI LABORATORY SURABAYA

\begin{tabular}{|c|c|}
\hline Ability Indicator & Training Value \\
\hline \multirow{4}{*}{$\begin{array}{l}\text { Implementation of } \\
\text { ISO } 17025\end{array}$} & Implement clauses of general requirements, resources and management ISO 17025: 2017 \\
\hline & Approach to processes and functions of organizational structures \\
\hline & Get to know the sample documents for the new requirements of the laboratory quality management system ISO $17025: 2017$ \\
\hline & Knowing changes to ISO 17025 every 2 years \\
\hline \multirow{4}{*}{$\begin{array}{l}\text { Implementation of } \\
\text { Ak3 Chemistry }\end{array}$} & Know the Laboratory SOP \\
\hline & Use of safety tools when in an acid room \\
\hline & First prevention during a fire in the laboratory \\
\hline & Follow up on expired chemicals \\
\hline \multirow{4}{*}{$\begin{array}{l}\text { Profession Test } \\
\text { and Appeal Test }\end{array}$} & Follow up on damaged or improper equipment \\
\hline & Carry out proficiency tests and IRR appeal tests \\
\hline & Carry out proficiency tests and acirs appeal tests \\
\hline & Follow up on proficiency tests and appeal tests that are out of standard results \\
\hline \multirow{4}{*}{ Validation Method } & Tool calibration \\
\hline & Tool verification \\
\hline & Calibration between \\
\hline & Operation of tools \\
\hline \multirow{4}{*}{$\begin{array}{l}\text { Analysis according } \\
\text { to standard methods }\end{array}$} & Know the tool usage history \\
\hline & Monitoring temperature and humidity \\
\hline & Making Report of Analysis \\
\hline & Sample monitoring \\
\hline
\end{tabular}


TABLE 4.

TRAINING NEED ASSESSMENT FOR CONTRACT EMPLOYEE FIELD OPERATION AT PT. SCI LABORATORY SURABAyA

\begin{tabular}{|c|c|}
\hline Ability Indicator & Training Value \\
\hline \multirow{4}{*}{$\begin{array}{l}\text { Implementation of ISO } \\
17020\end{array}$} & Implement clauses of general requirements, resources and management of ISO 17020: 2017 \\
\hline & Approach to processes and functions of organizational structures \\
\hline & Get to know the sample documents for the new requirements of the ISO 17020: 2012 laboratory quality management system \\
\hline & Knowing changes to ISO 17020 \\
\hline \multirow{5}{*}{$\begin{array}{l}\text { Implementation of Ak3 } \\
\text { Chemistry }\end{array}$} & Providing medicines \\
\hline & Use of safety tools that must be used when in the field \\
\hline & First prevention during workplace accidents \\
\hline & Follow up on damaged or improper equipment \\
\hline & Following up on the conditions of field work \\
\hline \multirow{3}{*}{ Validation Method } & Tool calibration \\
\hline & Operation of tools \\
\hline & Know the tool usage history \\
\hline \multirow{2}{*}{ Operation Draugh Survey } & Know the requirements of the ideal draft survey \\
\hline & Following up on the results of draft surveys \\
\hline
\end{tabular}

\section{B. Types and Data Sources}

The data obtained in this study are as follows:

1. Primary data were taken from the object of research through the distribution of questionnaires with 97 contract employees and direct interviews with the head of HR. Research with primary data sources is data obtained through or derived from the first party that has a data.

2. Secondary Data are the data that supports the ongoing research. Secondary data in this study were obtained from library data and previous research.

\section{Measurement of Variables}

Capabilities identified and analyzed for training material needs are grouped into several levels of ability, namely:

1. The level of ability currently possessed

2. The level of ability needed in work/assignments

The level of ability and score according to the high grouping of assessment indicators is low, so for someone the respondent can use his choice score (according to what he has) for each ability, which is presented in Table 3. The levels of ability measurement were done by scoring, whose scale is from 0 to 9 by organizing scores and categories are presented in Table 4.

\section{Data retrieval method}

\section{1) Interview}

Interviews are conversations with specific intentions. Conversations are conducted by two parties, namely the interviewer who asks questions and the interviewer provides answers to the question. Interviews are used to communicate with the subject of research so that the data needed is obtained.

\section{2) Questionnaire}

Questionnaire is a method used to collect data. Questionnaire is a list of questions or statements used by researchers to get data from sources directly through the process of direct communication or asking questions.

\section{3) Training Need Assessment-Tools (TNA-T)}

TNA-T is a process of reviewing training material needs by comparing the work capabilities needed and the ability of work they have [4].

a. Determination of the value of work capability needed on average is taken from the assessment by the respondent on the work ability that must be fulfilled by an employee in a particular field in his position, in this study the Head of Unit, using the formula:

$$
\text { Job skills needed }=\frac{\sum_{\mathrm{i}=0}^{9} \mathrm{i} \times \mathrm{n}_{\mathrm{i}}}{\mathrm{N}}
$$

Description:

$\mathrm{i}=$ Scale value

ni $=$ Number of respondents who assess the scale $\mathrm{i}$

$\mathrm{N}=$ Total number of respondents

b. Determination of the value of current work ability owned is taken from the respondents' assessment of the actual work ability of an employee at a certain position and calculated using the formula:

$$
\text { Current job skill }=\frac{\sum_{\mathrm{i}=0}^{9} \mathrm{i} \times \mathrm{n}_{\mathrm{i}}}{\mathrm{N}}
$$

Description:

$\mathrm{i}=$ Scale value

$\mathrm{ni}=$ Number of respondents who assess the scale $\mathrm{i}$

$\mathrm{N}=$ Total number of respondents

Training needs are determined by calculating the difference between the required work ability and current work ability, if the work ability is needed - current work ability $>1$ then training is needed.

c. Ranking of training needs is determined by the Peringkat Kebutuhan Pelatihan (PKP) diagram. PKP is determined by determining the intersection if the work ability needed and the ability of work that is currently owned. The intersection point of these two values will be located in the fields A, B, C or D. Based on the location of this intersection, the rank of training requirements can be determined based on the specifications of each employee's needs, as shown in Figure 1. 


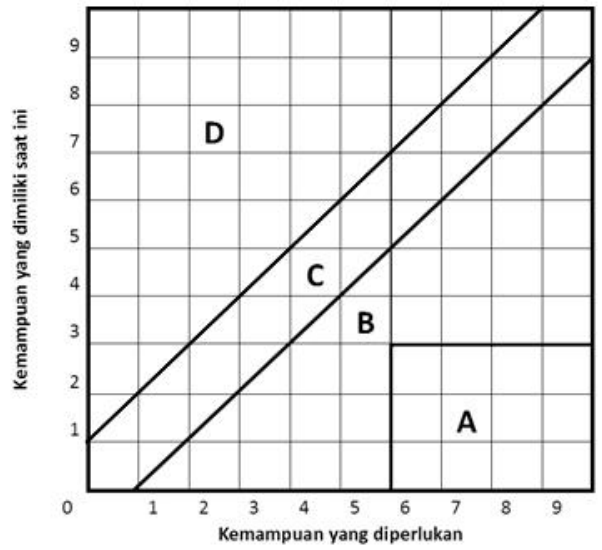

Figure 1. Training Need Analysis Diagram

\section{4) Focus Group Discussion (FGD)}

The FGD according to Irwanto is a process of collecting data or information about a particular problem that is very specific through group discussions. The FGD method is not done individually and is not free discussion without specific topics. A few steps:

1. Preparation in the team

2. Preparation in Groups

\section{RESULTS AND DISCUSSION}

\section{A. Characteristics of Respondents}

PT SCI Laboratory Surabaya contract employees who were the subjects of this study amounted to 97 of 112 employees. The researcher divided the respondents into 5 characteristics, namely based on occupation, age, sex, education, and length of work. In table 3 grouping characteristics of respondents based on work placements, employees divided into 2 fields, Office operations amounted to 37 people, and Field operations totaling 60 people. Office operations consist of analysts, administration and HR staff, while Field Operations consist of preparators, surveyors and drafter.

On the age category, under 30 years there are 83 people and over 30 years are 14 people. Employees over 30 years who survive working under contract, most are employees who will be proposed to become permanent employees. However, with the status of employees who are still in contract, age can be an assessment to measure work productivity.

From the gender category, the number of male employees is 80 people, female employees are 17 people. It can be seen in the table below that PT SCI Laboratory Surabaya prefers male worker over female worker. This can happen because the positions for Field Operations are far more than Office Operation's positions.

Based on the education category, SMA/K graduated are 15 people, D3 graduated are 31 people, D4/S1 graduated are 48 people, S2 graduated are 3 people. The level of education for contract employees themselves depends on the position to be placed. The education level of the SMA/K is a contract employee who is placed in the field operations, such as preparators and drafter.

From based on the time period of work category, employees with $<1$ year of work are 5 people, 1-2 years are 15 people, $2-5$ years are 62 people, and $>5$ years are 15 people. The length of work for employees who are directly contracted by PT SCI gets a 5-year contract with a 2-year, 1 -year and 2-year contract system. Whereas for the duration of work the employees contracted by the cooperative are 2 years long contracts.

\section{B. Results and Discussion based on questionnaire survey}

Based on the results of a survey of contractor training needs in PT SCI Laboratorium Surabaya, there were various assessments in each field of operation of the Office and Field operations according to the training indicators. The training in the questionnaire survey assessment were taken based on the training most often carried out by PT. SC Laboratory, at least every 2 years during the training. The research capability indicators are divided into training materials as presented in Tables 3 and 4.

This assessment is divided into 2 parts, valuation based on contract employees individually assessing their own abilities at present. Then the assessment needed/needed by the contract employee is assessed by the supervisor directly from the employee, namely the laboratory supervisor. Calculations from survey results and questionnaires as exemplified in appendix 2 obtained a training needs assessment chart.

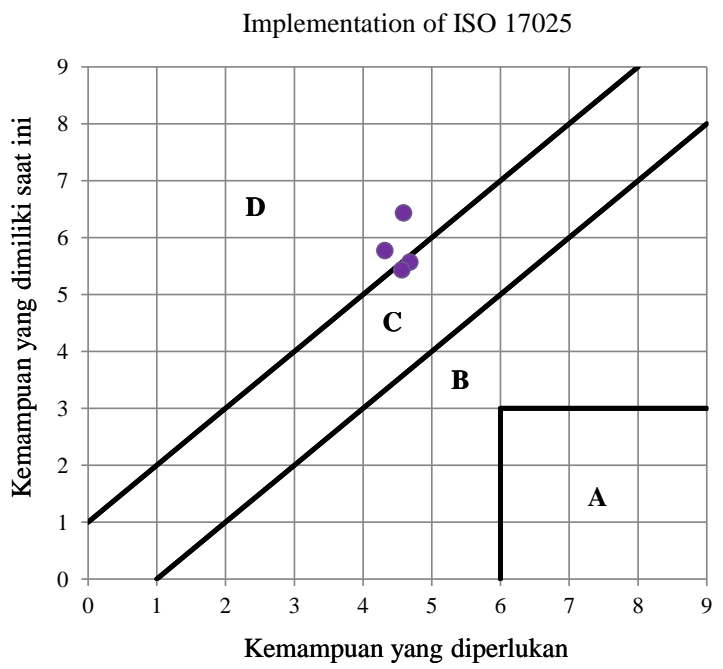

Figure 2. Training Needs for Ops. Office Contract Employees based on Implementation of ISO 17025 Training

From Figure 2 shows that the training needs with the capabilities possessed by employees now have value in area $\mathrm{D}$. This area is that this area has received very adequate training, training can greatly help employees in their work. Therefore, ISO 17025 training is considered sufficient for employees of PT SCI Laboratorium Surabaya. And this 
area is an area where career development for employees, namely by increasing career paths.

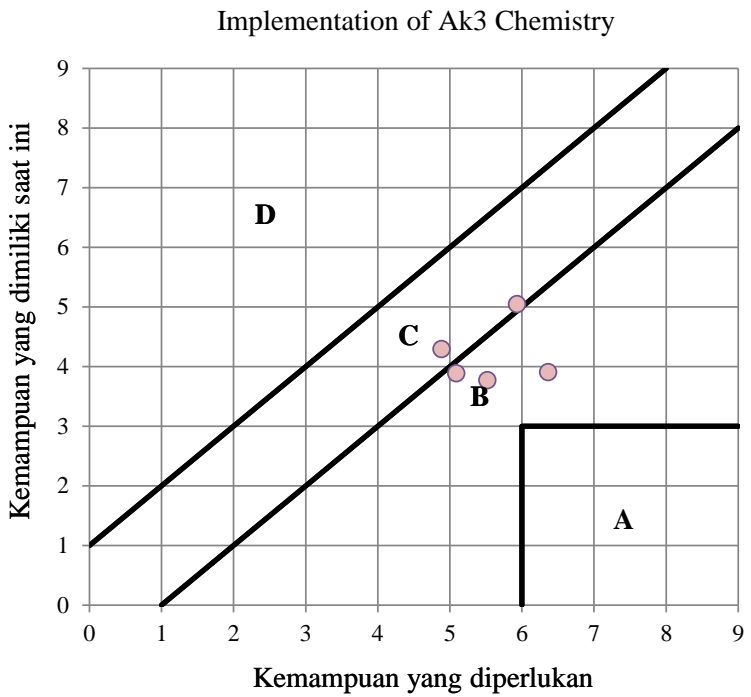

Figure 3. Training Needs for Ops. Office Contract Employees based on AK3 Chemistry Training

Figure 3 shows different results from Figure 2, where Figure 3 has a large spread point in area B. This area B is an area that requires training, Ak3 Chemistry training is very necessary for employees of PT SCI Laboratorium Surabaya because the training was managed by the second party of the company, as to why there are many employees who still did not receive the training. Training conducted by both companies tends to have limited participant quotas and implementation times which are only conducted once a year.

Professional Test and Appeals Test Training

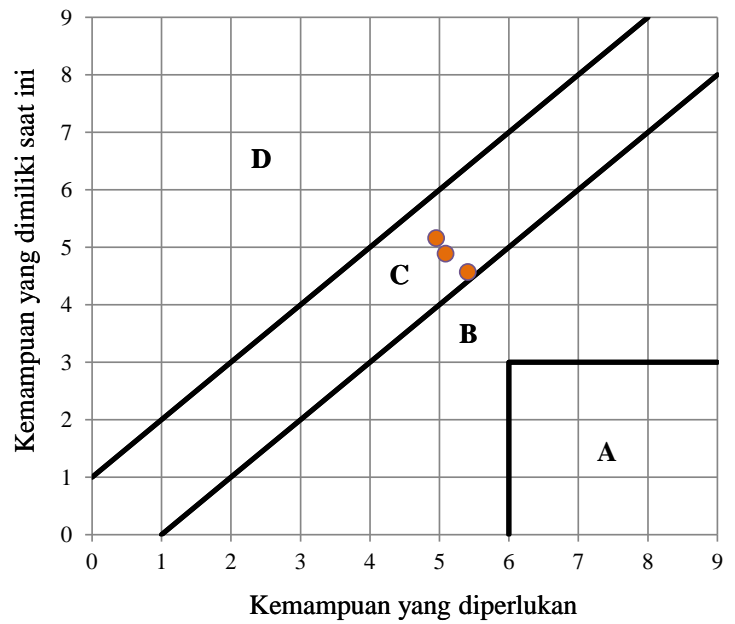

Figure 4. Training Needs for Ops. Office Contract Employees based on Professional Test and Appeals Test Training

In Figure 4 the proficiency test and comparative test training are in area $\mathrm{C}$, the assessment assessed by superiors and employees themselves has the same average value. Region $\mathrm{C}$ suggests that the training in this area is sufficient for the capabilities possessed by employees and future employee needs. The proficiency test and the comparative test are very rarely material changes, so employees and superiors consider training to be given once.

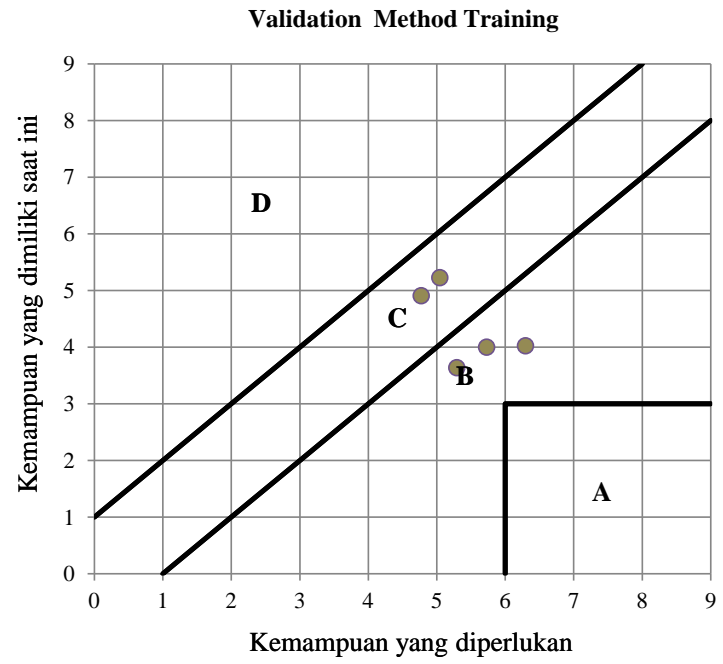

Figure 5. Training Needs for Ops. Office Contract Employees based on Validation Method Training

Then Figure 5 shows the average number of subjects in area B. However, there are 2 points that show in area C. If traced by the translation of method validation training material, 2 points in area $\mathrm{C}$ mean tool calibration and calibration between. In other materials such as verification of tools, operation of tools, and knowing the history of the use of this tool, it is only followed by employees who have basic quality control. Employees who have basic QC are only a few per division, so not all of them get this material. The method validation training itself is one of the training that is not required to be given annually for each Office operation. Therefore, all contract employees did not receive this training in 2017.

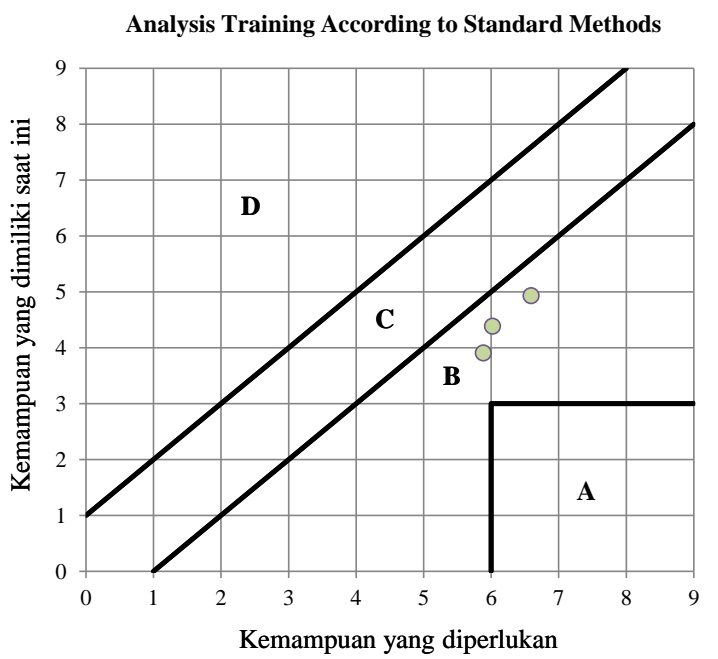

Figure 6. Training Needs for Ops. Office Contract Employees based on Analysis Training According to Standard Methods 
Figure 6 is a picture of the results of the analysis training according to the standard. This method shows points in area $\mathrm{B}$, meaning that this area requires training. This training is needed because there is a method update every year. The ISO method can change to the standard method used in PT SCI. The renewal of this method is closely related to ISO 17025, because these clauses in ISO 17025 have an analytical update method. From the results of the assessment above, it can be concluded that the much needed training is the Chemical AK3 training, method validation and analysis according to the standard method.

The TNA applied in this study greatly helped the HR department of PT SCI Laboratorium Surabaya. The HR department has some difficulties to coordinate participants in managing training every year, because trainees are usually only selected by the head of field policy. If the selection of trainees is subjectively chosen by the head of the field, then there will be a gap between old employees and new employees.

However, TNA itself has several advantages and disadvantages that can be discussed in the FGD. The advantages possessed compared to other techniques are in terms of minimizing subjective judgments from the party giving the assessment and the party being assessed, while the weakness is if the person who gives the assessment or is considered not giving honest information, so the assessment results will be bias [3].

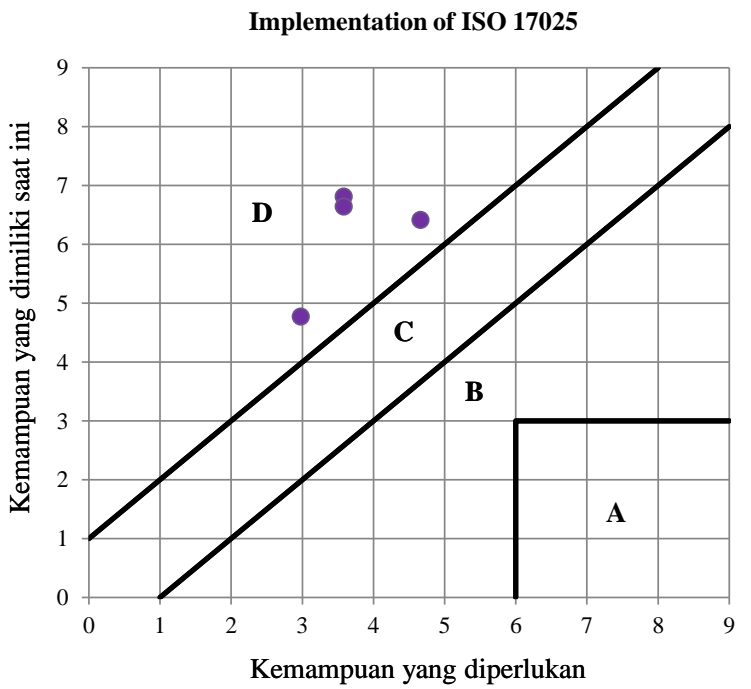

Figure 7. Training Needs for Filed Operation Contract Employees based on Implementation of ISO 17020

From figure 7 the application of ISO 17020 is in area D, which means areas that require employee career development. Employees have received regular training for each ISO 17020 change. So that this training is felt to be sufficient for employees and there is no gap between employees. Fields operation employees can develop their careers through career paths to become internal auditors for ISO 17020 training materials in companies such as PLN, CJI, Smelting, and other companies.

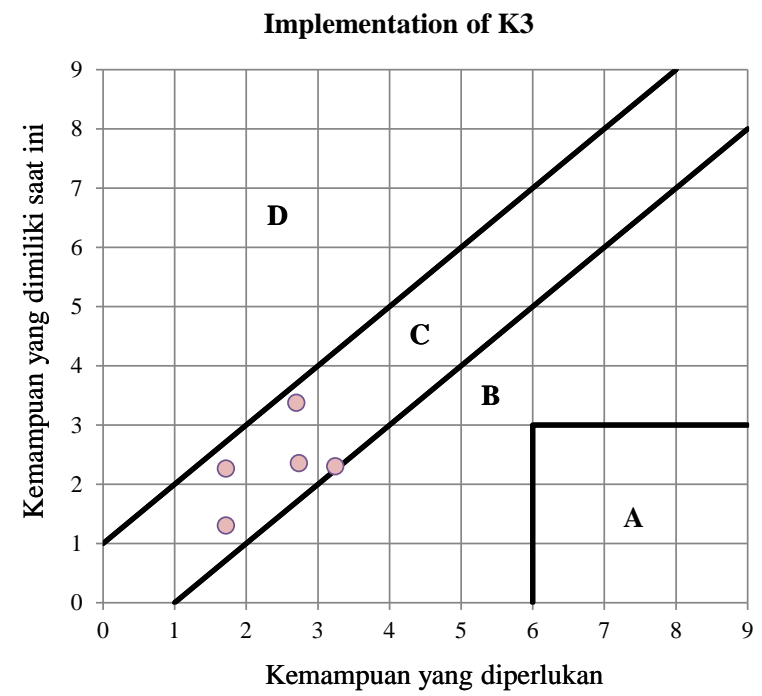

Figure 8. Training Needs for Filed Operation Contract Employees based on K3 Training

Figure 8 General OHS (Occupational Health and Safety) implementation, namely training on SMK3 implemented at ISO 45001: 2018. This training has results points in area C, areas that are sufficient in getting training. General OHS (Occupational Health and Safety) training as well as Chemical AK3, the training is held by both companies. However, field operations employees are required to receive this training because PT SCI (Enterprise) is a company engaged in certification, inspection, testing and consulting. Therefore, PT SCI Laboratorium Surabaya needs to plan and implement measures to deal with SMK3 risks and opportunities, namely by holding this General OHS (Occupational Health and Safety) training.

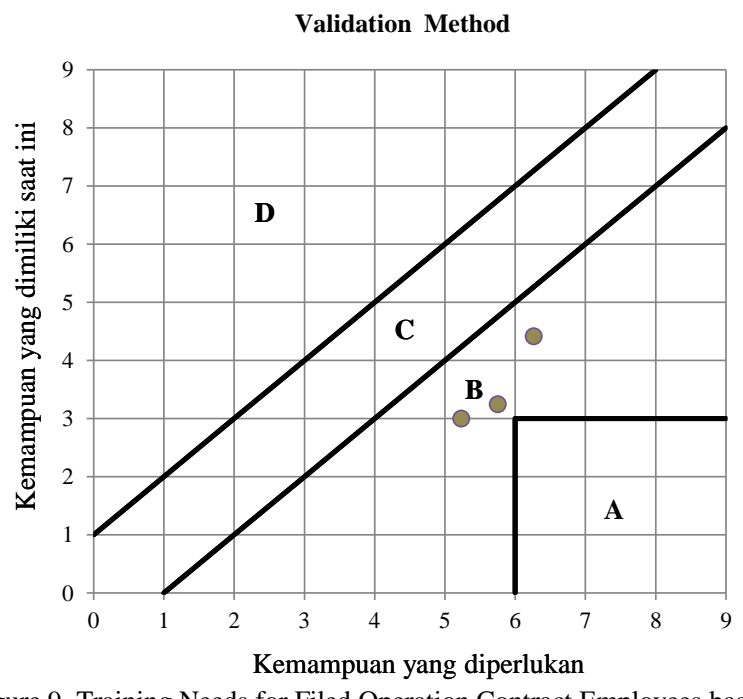

Figure 9. Training Needs for Filed Operation Contract Employees based on Validation Method Trainin

In Figure 9 shows a picture of method validation training, the results of this point are in area B. Training that discusses the calibration of the tool, the operation of the 
tool and the history of the use of this tool is needed by Field Operation employees. Because the employees are placed at work on the project, so employees are expected to understand the tools used. However, there were several Field Operations employees assigned only for assistance. When an employee is in charge of being a chaperone, the employee is not allowed to approach the tool at all by the client. This led to training in calibration of equipment and calibration between Field operations employees, not much was given to each employee according to the direct supervisor who assessed.

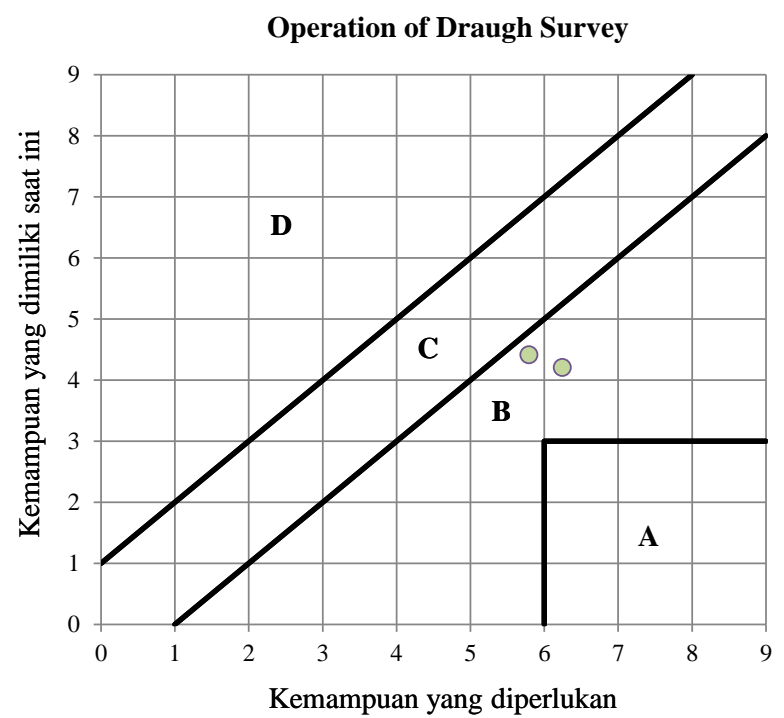

Figure 10. Training Needs for Field Operation Contract Employees based on Operation Draugh Survey Training

Figure 10 is in area B, this area needs training. Field operations employees need training in knowing the requirements of the ideal draft survey and following up on the results of draft surveys. The results obtained can lead to disparities between employees, both those who have attended training and those who have not attended training. In addition, these results can affect the performance and productivity of employees, if not immediately responded.

\section{Results and Discussion based on Focus Group discussion}

Based on the results of the minutes as written in Appendix 3 , the results of the FGD, Focus Group Discussion (FGD) were held on Friday, March 22, 2019, located in the 3rd floor meeting room of PT SCI Laboratorium Surabaya. The FGD was attended by 1 moderator named Nia, 1 minutes named Dita, researcher, 8 participants, Head of HR and 1 supervisor. Participants were drawn from 2 people from the MINERBA division, 2 from the Serco division, 6 from the Environment, Micro and General (EMG) divisions. The FGD starts from the preparation and introduction of material to participants about research, research objectives and Training Need Analysis (TNA) material.
In this FGD 6 main questions were presented which would be a discussion material for the participants. Each participant can express his opinion. The FGD lasted 1 hour and the FGD results were obtained as follows:

1. Do FGD participants know or are familiar with TNA?

The results of the discussion: HR, supervisors, heads of fields and participants who already knew about TNA, some of them did not know. The percentage in knowledge about TNA is only $30 \%$ of the FGD forum. So the researcher gave a little socialization about TNA and the function of TNA.

2. The results of the research survey show that there are still many employees who have not attended training in 2017. Are there many participants who still have not received compulsory training listed in the survey assessment sheet?

Results of the discussion: from 2 participants representing each field/division one had found the training and 1 had not yet received training in 2017, but in 2018 there were those who had received the training. For the AK3 Chemistry training the participants have not all received training, general OHS training was conducted last in early 2017. And from the FGD participants there were not only supervisors and field heads who had attended the training.

3. How did the participants who were not selected take part in the training during the training when they were not appointed to take part in the training?

The results of the discussion: the participants gave the opinion that those who did not attend training in 2017 had three possibilities:

a. They have received the training in 2016 .

b. They did not attend the training well in previous years and in 2017.

c. They received the training in 2018 .

Jealousy can occur when they are not trained, other than because their material sometimes chases snacks and food. For gaps can occur, when those who are followed for training are people who have attended the training twice a year.

4. From the results obtained from surveys with supervisors and contract employees, there are several trainings that are actually still needed. According to representatives of survey fillers and questionnaires who were participants, could the training be a gap? And affect the performance and productivity of work?

The results of the discussion: for gaps, until now the participants felt that there had not been a gap, but if it was seen from the performance appraisal, there are some participants who have decreased performance levels. This affects the next job and affects the results. Usually the gap also occurs because the training obtained is an additional point for employees to fill in the CV. From this $\mathrm{CV}$, it will also affect the level of appointment of contract employees to follow the internal recruitment of permanent employees. 
5. How much influence does this TNA have on participants and HR?

Results of the discussion: Through this research the participants were very happy when the TNA program was being held. Their reason is because sometimes training is carried out at the wrong time. Prospective participants sometimes have a lot of work responsibilities, but are appointed to be as well as training. If there is TNA, HR can choose other participants according to the needs and abilities that the prospective trainee does not yet have. And HR feels helped in choosing training participants, because all this time HR has had to pass through prospective participants personally. If there is a TNA SDM that is much easier to work and prospective trainees have no reason to refuse.

6. Who needs to contribute to further TNA implementation?

Results of discussion: HR and head of field. HR from PT SCI Laboratory is grateful for this research. HR also hopes that this TNA method can be continued in the future.

\section{Managerial Implication}

The results of the training needs analysis study at PT SCI Laboratorium Surabaya, showed that the training had been carried out as well as possible. Some training shows the results of needs that can be recommended for training to be held again. The training held again aims to improve employee performance, in addition to that employees can develop their careers and there is no gap factor between employees. The training was held aimed at developing the skills, knowledge and attitudes of employees. Then the results of the training are applied to all employees as an evaluation of training material that has not been understood by employees.

Before planning training for employees, employers need to conduct organizational, operational and personnel analysis so that training can be effective and on target. From the results of the training needs analysis for employees of PT SCI Laboratory Surabaya's contract employees in the employee's office operations requires training in ak3 chemistry, method validation and analysis according to standard methods, field operations require training in draft survey validation methods and operations.

Employee contact training at PT SCI Laboratorium Surabaya is held at least once a year and binually (6 months) or 3 months if there is new knowledge that needs to be immediately disseminated to employees. The following are training recommendations for contract employees, as seen from the results of the analysis of current capabilities and required capabilities shown in Table 10.
The training recommendations in table 4.9 are taken from the target trainees each year and also from the survey results to employees. These recommendation trainings aim to improve performance, productivity and eliminate gaps between contract employees. A total of 34 contract employees assigned to office operations have the right to receive chemical training, specifically for handling security in the laboratory. Chemistry Training can be done using the off job training method where training is held by a second party. The number of participants applied for method validation is 27 contract employees. Then, for recommendations for analysis of training according to the standard method, 15 people were followed.

In the field operations section, participants who followed the validation of this method were recommended for 33 contract employees. The contract employees in this field receive training according to validation methods that refer to the standard methods applicable in PT SCI. Then, for operations training draft surveys were recommended with 17 prospective participants. Method validation training for office operating contract employees, analysis according to standard methods, method validation for field operations contract employees, and draft surveys carried out using the on-job training method. This training takes the form of assigning employees under the guidance of experienced supervisors (senior).

\section{CONCLUSION}

Based on the results of research using the TNA-T method, it was assessed that PT. SCI Surabaya Laboratory still needs training. From the number of studies on 97 contract employees divided into Office and Field operations. The design of TNA for 2019 is the training of Chemical AK3 as many as 34 people for Office Operations using the off job training method, 27 people need method validation training, and 15 people need analysis training according to standard methods. TNA for 33 field operations employees needed method validation training and 17 people needed draft survey operation training. Training other than AK3 Chemistry is recommended to use the on job training method.

\section{REFERENCES}

A. Rahman, "Pengembangan pegawai melalui perencanaan pelatihan yang efektif," J. Borneo Adm., vol. 6, no. 2, pp. 1-17, 2010.

[2] H. Hendriyaldi, "Pengaruh pelatihan dan motivasi terhadap produktivitas manajer PT. Sucofindo (Persero)," J. Benefita, vol. 2, no. 3, pp. 255-266, Nov. 2017.

[3] I. Arep and T. Hendri, Manajemen Sumber Daya Manusia. Jakarta: Universitas Trisakti, 2002.

[4] G. Dessler, Management of Human Resources Edisi Bahasa Indonesia. Jakarta: Prenhallindo, 1997. 